\title{
A Post-Soviet Empire?
}

\section{Post-Imperial Reading of the Nationalities Policy}

\author{
Andrei A. Teslya, PhD in Philosophy \\ Immanuel Kant Baltic Federal University, Kaliningrad, Russia \\ Institute for Humanities \\ Research Center for Russian Thought \\ Scientific Director, \\ Senior Research Fellow \\ SPIN RSCI: 616154 \\ ORCID: 0000-0003-2437-5002 \\ ResearcherID: E-9127-2015 \\ E-mail: mestr81@gmail.com \\ Tel.: +7 4012465917 \\ Fax: +7 (4012) 46-58-13 \\ Address: 14 A, Nevsky Str., Kaliningrad 236016, Russia \\ DOI: $10.31278 / 1810-6374-2021-19-2-164-182$
}

"Russia's current foreign policy is both post-imperial and post-Soviet. The prefix 'post' does not mean impotence or uncertainty. It means that the present is predetermined by the past, it is the inheritor of the past. The inheritor is dissimilar from what it inherits and as long as the inheritor remains dissimilar and not fully aware of its own identity, it continues to be 'post'."

That was the preamble that opened Alexander Solovyov's interview with philosopher Andrei Teslya.

\section{POST-SOVIET EMPIRE?}

- What is Russia today - a state that seeks to become an empire, or a state that struggles with its inevitable fate of becoming an empire?

- To begin with, I would describe Russia's current state as a post-imperial construction model. True, its supporting framework is imperial, but this imperial framework is not "Russian." It is a model of a "new Soviet Union," 
and not a new Russian Empire. The difference lies in federation as the legal principle on which Russian statehood rests. All allusions to the experience of the Russian Empire are made either symbolically, or through experience of the Soviet Union, reconsidered from the standpoint of the current realities.

And it is not a "reincarnated Soviet Union," at least because in this model there exists only the RSFSR - the Russian Soviet Federative Socialist Republic. Even if we take the Soviet imperial construct and hack off all other union republics, the resulting construct will be different.

An empire has several important attributes. An empire always implies the ambition to achieve universality. Imperial logic is the logic of universal inclusion. The imperial border is not identical to the border of a nationstate. The imperial border lies there where the empire has stopped its expansion at a particular moment in time.

Modern Russia has some problems with universality. We can see an imperial model of construction that lacks the imperial content. There are residual structures which cannot be easily replaced with nationality-based ones, because attempts to do so will be fraught with an explosion.

Today Russia follows the logic of an inertial scenario. On the one hand, there are attempts to build a civil community. This implies a common language, cancellation of the special status of territories, cancellation of the special status of minorities' languages, and so on. On the other hand, it remains unclear what can serve as a basis and instruments for building an effective civil national community. And here we encounter the problems of historical narrative. As soon as we turn to history, we find ourselves within the framework of a large Russian nation and imperial history. As a result, this history automatically turns into a history of losses, a history of defeats, a history of an empire in retreat...

\section{- Revanchism, ressentiment...}

- Quite right. All this stems from the very same historical construct. If you stick to this historical construct, you will have no chance of interpreting this history in a different way.

Consequently, if there is no search for a different foundation and a different construct, the only option left is the condition of an empire in retreat, and also of revanchism and ressentiment. 
- Does such an empire have the potential of a state of nations?

- An empire and a nation in the context of modernity are not antagonists. Who are the builders of nations? The very same empires. What was the Soviet Union in relation to the Russian Empire? On the one hand, it was its gravedigger.

\section{- And its successor.}

- Furthermore, what was this successor's achievement and defeat at the same time? It assembled the territories, except for the Kingdom of Poland and Finland, into the same entity, but it was able to do it by changing the principle of construction. It changed the method of assembly, and by doing so it preserved the empire. One of the key features of that construct was that the empire truly worked with nations and nurtured nations within its framework. Just like the Russian Empire in the 19th century, the Soviet Union tried (and, just like the Russian Empire, not without success) to raise its own imperial nation. In the case of the Russian Empire, it was the Great Russian nation.

- Will it be correct to say that it incorporated different ethnic groups by absorbing them without assimilating them?

- At this point I would refer to Vishlenkova's classical work with a wonderful subtitle, Not Everyone Can See the Russian (Vishlenkova, 2011). It is about the first half of the 19th century and about how an image of the Russian was created in those days. Why was it created? Why did it become important to see the Russian? And what does it all mean?

We can offer two interpretations of Sergei Uvarov's well-known construct, in which he described nationality through two other notions. The classical explanation would be that it was Uvarov's cute trick: in fact, he made the notion of nationality empty. But I think a different interpretation would be more reasonable: Uvarov just had nothing to rely upon that could let him speak of some positive content of nationality.

- But it was his personal intellectual construct. He was a Russian nobleman with a French education and a poor command of Russian.

- And he formulated his doctrine in French, which strongly distorts meanings. Moreover, the debates about nationality in Russian literature 
unfolded in the 1820s. Those were debates about primary matters like "What, in fact, is nationality?"

- It was an attempt by the elites to understand what 'nation' is, or to present it somehow.

- To describe it through some characteristics, a set of images, and to draw some borderlines showing where "nation" is and what it is like. So, there occurs the process of description, the process of construction, and the process of identification. It is a project of a Great Russian nation, no matter which way you look at it.

It is an option that does not exclude second-order identities built into it. It is an identity that includes Western Russians, Great Russians, and Little Russians. But the key thing is that these are identities built into the Great Russian nation.

- Connected with imperialness.

- Imperialness is the pillar. Clearly, an empire is unable to spread the logic shared by the members of a national community onto all of its subjects; likewise, it is unable to make all of its subjects part of the nation. Consequently, it is the majority that is to become the imperial nation, and this majority must be constructed and united.

- Wasn't it exactly what the Soviet Union tried to do? To create the identity of 'Soviets' - the term to be applied not even to the majority but to the whole population?

A. The Soviet Union originally followed a very different logic-the logic of uniting national communities. This is the logic of Mykhailo Drahomanov. In his last work, The Letters to the Middle-Dnieper Ukraine, Drahomanov writes about what we usually attribute to Joseph Stalin, although Stalin merely quoted an author who had written that 19 years earlier (Drahomanov, 1915; Stalin, 1913).

Drahomanov writes that, firstly, a nation is the road to modernity. Modernity is socialism that we are moving to. He coined the famous construct: "National in form, socialist in content."

But the Soviet Union's policy changed greatly over a not very long period in history. There was an attempt to build a common identity, a macro- 
affiliation, a new historical community of Soviet people. It was to become the basic one. But its relations with national communities turned out to be very complex.

It is important to stress that at this point there emerges a very complicated relationship with Russianness. On the one hand, the Soviet Union was an agent of a strong Russian cultural influence, and not only within its national borders, but in its immediate neighborhood as well. On the other hand, we cannot describe Russians as an imperial nation in the classical meaning of this notion.

- The Soviet Union was a crossbreed of an empire and a state of nations, wasn't it?

- In principle, yes, it was.

\section{UNDERSTANDING THE NATIONAL}

- I reckon we have problems with the national all along, starting from understanding it properly. Some five years ago, Sergei Sergeev in his book The Russian Nation claimed that the Russian nation had never taken shape, at least, as a civil nation. What do you think about this?

- To begin with, I would specify Sergeev's idea. As far as I can remember, he wrote that the sole moment in history where the Russian nation could be regarded as an established and effective actor was the period from 19051906 to 1917 . This clarification is important, for it shows the construct Sergeev had in mind.

The way he sees it, a civil nation implies representation, which is very traditional. For him, the history of a nation in terms of modernity is a history of building a modern community, and the latter implies the formation of modern political institutions.

\section{- This construct is self-sufficient.}

- Yes, it is. One doesn't have to write a book for this, it is enough to formulate the basic definitions and put a full stop. I think the problem is somewhat different. It is an attempt to use, for Russian nationalism, for instance, a habitual language (easily understood by those who are not specialists on the subject) - the language of the revolutionary-liberation 
movement. The whole history will then appear as a history of centuries-long suffering of the people under the yoke of... and so and so forth.

\section{- Under the yoke of politically alien power. Politically, not ethnically?}

- Sergeev draws a picture of not national but some autonomous power, an autonomous state system that acts in accordance with its own logic. In its own logic it can achieve the highest effectiveness, and it can create and support enormous structures. But the people in this situation is an object, a building material.

So, according to Sergeev's logic - if I reconstruct it correctly-for those who take a national position, the history of state-building is the history of something alien. It is not your history. Your history is the history of oppression; "their" victories are not your victories and "their defeats" are not your defeats. In this case you are either a victim or, at best, an onlooker. In this situation one is fortunate if he remains unnoticed by this structure. For the "little man" it is always a piece of good fortune. Not quite so for a group, because a group can "slip out of history" only by ceasing to exist.

- In other words, the common man is not an actor in that history, but an object or an outside onlooker.

- Quite right. But even in the nationalist logic it is a very strange attempt - if the language of nationalism of the late 19th-early 20th centuries is to be used-to position oneself as a "plebeian" nation. This is reminiscent of the history of Ukrainness, in which statelessness was the key problem of historical narrative. Everybody confronted it-from Drahomanov to Grushevsky and Lipinsky (see Teslya, 2014, 2016).

The task was to find in the past some sort of own statehood, a fullfledged class structure, something that the current ideas of statehood could rest upon, to interpret the events of the 17th century not as a history of popular movement, in contrast to the first generations of Ukrainness, but as a state-building experience.

Sergeev tries to describe the very same phenomenon, but in the logic of the oppressed. But this logic is not just the logic of the victim of a certain historical period, not the history of the loss of, say, agency. If we take Czech 
history, for example, we will see that it was the history of acquisition of agency, existence in agency, and then loss of agency.

Where does all this logic of national revivals come from? It is about getting back what you once had. It is the logic of those not represented, disfranchised, absent; the logic of those who wish to be heard and of those who are to be subjected to positive discrimination.

- If the scholars' logic looks faulty, then the logic of bureaucrats is still worse, isn't it? At a certain point, the law "On the Russian Nation" began to be drafted. The very name looked somewhat frightening. Then a decision was made to "rename" the law, which resulted in an utterly bone-rattling bureaucratic monster...

- Several important remarks should be made in this respect. On the one hand, the term 'Russian' does not encompass all citizens of the Russian Federation. On the other hand, the logic of multi-nationality as such conceals another very important component. If we speak about the plurality of nations, the plurality of groups and the plurality of national communities, then the question of the Russian nation inevitably rises to the surface. Next comes the question of representation. Let me stress once again that the very word "Russian" is loaded not only politically, but emotionally as well.

Inside Russia, too, national groups are regarded as having special status. Let me remind you that in our legal acts the list of the constituent members of the Russian Federation-although all equal-is hierarchic: republics come first, territories second, regions third, and so on.

- But the national factor hardly plays a role here. This should rather be attributed to the customary vertical chain of command.

- It is noteworthy that at the very top of the list are the republics, which are nationality-based. The list as such is quite telling and capable of evoking mixed feelings. For instance, from the standpoint of a Russian nationalist it is insulting that the republics come first, while a nationalist of a different sort may feel offended by the fact that the autonomous areas are at the bottom of the list. This is not an alphabetical logic, but the logic of different political statuses. 
From this point of view 'Russian' may look a neutral term. 'Russian' is no one particularly, someone with no special features or identity. Consequently, any other national identification, affiliation with a different nationality is tantamount to laying claim to a different status.

On the one hand, we say that we have an equality of civil statuses and equality of territorial entities. On the other hand, Russia is an unbalanced federation. Moreover, legal acts most often state the opposite, which forces all parties, as soon as they employ the legal language, to say things that have nothing to do with reality.

\section{- This is a rather typical situation for Russia, isn't it?}

- I would not say that it is very typical. When the basic and legal constructs are in stark contrast to reality, that is one thing. But an attempt to postulate a special legal status of other national groups, in fact, implies departure from the universal concept of citizenship and the basic constructs of modernity.

\section{- Our traditionalists do not like modernity anyway, do they?}

- Yes, but if we speak of different varieties of Russian nationalism, these are all attempts to use the language of high modernity one way or another (see Krylov, 2010; Sergeev, 2010, 2017). But as soon as we drift away from the most general formulas to some specifics, we again get the very same problematic picture. In opinion polls, most of the respondents define their nationality as Russian. But this overwhelming majority is a demobilized majority. The name of this identity for a majority of those who position themselves this way is not loaded, or very weekly loaded. In the meantime, most other groups are far more mobilized.

So, we have the demobilized majority and the mobilized minorities. This problem is not resolved at the level of the logic of assertion or citizens' self-identification as Russian. Or, to be more precise, such an approach also means that all other groups, rather mobilized ones, are automatically declared as non-citizens of the given national community.

Attempts by states to demobilize some groups result in the mobilization of others and the emergence of new groups. Importantly, the way of their formation and mobilization is equidistant from the state-nation and 
the nation-state. The logic of total demobilization does not work, but demobilization sometimes occurs all by itself wherever it is crucial. By solving one problem, tactically important, you get another one in the long run.

\section{- Is it possible to track direct influence of mobilization and/or demobilization of different social groups on foreign policy?}

- In some cases, yes; in others, no. If mobilization occurs in some ethnic groups (within a multi-national system), they are capable of influencing some aspects of foreign policy. For example, the mobilization of the Armenian community inside Russia at the end of the 19th century resulted in a considerable adjustment of the Russian Empire's policy towards the Ottoman Empire. Simultaneously, that mobilization caused changes in the domestic policy, above all in Russia's Transcaucasia. The attitude to secret societies changed, too. The Armenian national movement Dashnaktsutyun became an autonomous policy actor. Many of Russia's Armenians were affiliated with this movement or supported it. At a certain point the Russian Empire realized that Dashnaktsutyun had its own logic and began to treat its Armenians as potential opposition.

\section{- Is the empire answerable for what is happening in its periphery,} on its outskirts?

- This is a difficult question, because it involves the problems of responsibility and institutions. Responsibility can be offhandedly interpreted in ethical terms and then we instantly come to several questions: To what extent and in what way is ethics applicable to institutions and collective actors? Is it possible to discuss - not metaphorically - the ethical responsibility of the state and its limits and the identity of an actor in time (incidentally, the same question applies to the responsibility and self-identity of an individual)? Getting away from these questions is also difficult because ethics strongly intervenes in politics - the ethicization of politics, which reached a new level in the 1990 s and the 2000 s, has retained much of its original power.

In any case, the empire is "answerable" for what is happening in its periphery. All events on its outskirts are of importance to the empire's foreign and domestic policy: it is responsible, for instance, from the 
standpoint of demonstrating and confirming its ability to project power, maintaining order and preventing external forces from intervening in the events afoot there (the latter, in fact, asserts the periphery's status in relation to the given empire), or sanctioning the inclusion or exclusion of these forces, etc.

Importantly, there may be different regimes for different peripheries and this distinction may be quite clear for the entities involved. In other words, certain practices and actions taken in one periphery may have no bearing on another, or they would be inapplicable or out of place there. Alternatively, the situation in one periphery may be presented as an example to follow.

Also, there is the problem of confirming and preserving one's statusor strengthening or losing it in the eyes of others. That is, there is the question of self-responsibility, preservation of self-identity-or the need to redetermine, reconsider, and reassemble oneself. If you are unable to reinvent and reassemble yourself, then the only option left is to keep to the previous logic at any cost and push ahead with the previous mode of action as long as your strength permits.

- Is expansion-cultural, economic, and territorial-a "constructivist" element of self-identification that is subject to consideration, control and self-restriction or an inalienable property of an empire?

- "Everything that exists tends to expand." In this respect the policy of defense, or retention is nothing but an individual case when there is no strength or opportunity for expansion, and the sole option left is to try to retain what one has-not in absolute values, but relative ones. One's expansion may appear not a consequence of one's growing strength, but of decline and reduction in the strength of someone else, or of the emergence of a vacuum that begins to be filled by the one who proves capable "here and now," even if his potential does not grow but declines, but at a slower pace than that of the others.

It is a different matter that the relevance of the language of "expansion," let alone the simple and straightforward language of imperialism of the late 19th and early 20th centuries, is increasingly often called in question. It has become "more decent" to express the same meaning through various "horizontal" notions like "interaction," "cooperation," etc. 
But what is more interesting to me is to what extent territorial expansion and search for direct control of certain territories will again be brought into the foreground in our time and in several decades to come-instead of different forms of indirect domination, which prevailed in the expansion logic of the post-Yalta world and which were far more mobile and provided a variety of forms/options for both compromise and hostile interaction without direct conflict.

\section{NATIONALITIES POLICY}

- Is it right to say that the nationalities policy emerges only after nations appear? Or does the nationalities policy exist before nations take shape?

- I don't think there is a simple answer to this question. The formation of nations is a long process. It is also a reflexive process. In this sense, politicians' actions that we describe as nationalities policy acts are factors for the appearance of a national community as such. It is a dual process that brings into being rather noticeable agents that identify themselves in these categories, find the corresponding audiences they can address and the corresponding groups they can rely on.

In general, the question of whether it is possible to define the 19th century as a "century of nations" remains highly debatable. Apparently, it will be more reasonable to say that the 19th century was a century of empires or, closer towards the end of the century, of "imperialism" (Osterhammel, 2014; Berger S. and Miller A., 2015). At the same time, it was in the 19th century that the main agents identified themselves through such key categories as national interests and national policies. Mutual complaints that different groups actively exchange in domestic policies are a clear indication that the authorities pursue a policy that is obviously not a national one.

- In other words, the terms 'state interest' and 'national interest' may or may not be synonymous?

- Naturally. Moreover, the very notion of state interest is associated with the 17th century and its actualization by the French romantics of the 1820s. The personality of Rechelieu-equally enchanting for Alfred de Vigny 
and Alexander Dumas - is quite significant in this respect. De Vigny would place the conflict between the old ideas of honor and glory and the new state system in the center of his most famous novel and one of the most notable works of French romanticism of the 1820s-Cinq-Mars (1826) (see Reizov, 1958, Ch. III). When we turn, for instance, to the 17 th century, the categories of state interest, raison d'etat, the notion of national interest is not found there. In that period the state interest was understood with no regard for what would be called national. And a very important problem-to what extent the state interest coincides with national interest-emerged in people's minds later (Meinecke, 1924).

Today, theoreticians actively discuss the problem of the state as a form of order that cements society; and to what extent a conservative can be certain that the state really acts in the state interests, and even more so in the national interests. To what extent, for instance, the state is not seized by other groups. This is where the widely known logic of conspiracy theories emerges (Boltanski, 2012).

- It looks like this discussion proceeds as a rather constructivist, structuralist narrative. The participants in the discussion agree on a set of terms and on how they would define the processes discussed. Also, such a discussion implies certain civic consciousness because a conservative can be concerned over such issues only if he feels like a citizen.

- Yes, this is another aspect of interest. Throughout the 19th century, European conservatism changed fundamentally. Whereas at the beginning of the 19th century conservatism - if it is to be described in very simple terms - was an anti-civic logic, a logic of the "throne and altar" which triumphed immediately after the Congress of Vienna...

\footnotetext{
- In very primitive terms, the logic of keeping the populace away from politics?

- Quite right. Politics itself was not built in accordance with the logic of the national community. But rather quickly, towards the second half of the 19th century, this logic of civic consciousness began to change, while nationalism as such and its idea began to be increasingly intercepted by the right-wingers. Let me remind you that in the first half of the 19th century
} 
the terms 'nationalist' and 'liberal' were practically synonymous: while talking about the nation you, in fact, talk about civil society, citizens, the logic of common rights of citizens, etc.

Clearly, there was virtually no room for conservative maneuver. But then there appeared other actors on stage, those who at first, in the 1830s, were called radicals and who, first in France and then in other countries after 1848 , would become socialists. This strongly modified the category of national interest. The advent of socialists ruined the previous pattern and, in fact, transformed the binary system into a ternary one.

\section{- They also brought with them such things as 'class conscience' and 'class interest.'}

- This is most amazing. 'Class conscience' and 'class interests' were first created by French doctrinaires and liberals, and later borrowed and considerably reworked by Marxism. The whole story began in the 1817-1819, when the doctrinaires had not yet manifested themselves and the reflection process was still underway. For the key figures of that story-Augustin Thierry, Francois Guiso and others-the discussion of classes spelled the end of the revolution.

Moreover, the aristocrats became the agent that kept the revolutionary processes going. The thing is that we are still in the regime of the 1814 Charter-the constitutional act Louis XVIII granted upon his ascent to the throne. It was an act of reconciliation after a quarter of a century-long revolutionary period that started in 1789 . The Charter ended the revolution: the whole history from the Frankish conquest to the revolution was a history of class struggle; first, it was tribal, and then class struggle. But the revolution eliminated classes. Classes ceased to exist. The third estate was gone.

And that was a very important moment: the third estate declared itself as everything, there were no more classes, there was only one nation. We got into a classless state, if Thierry's or Guiso's logic is to be followed. However, pretty soon it turned out that the classless state was a forerunner of the July Monarchy.

- You have mentioned earlier a discussion over the distinction between the state-nation and the nation-state. This also seems to be a 
somewhat abstruse constructivist discussion, but we need to understand somehow what is going on.

- I think this discussion highlights the problem related to what we call-in very general terms, of course-the death of grand narratives (Lyotard, 1984). The classical construct of the nation-state rests upon the image of an ideal citizen and his involvement. It rests upon the very same republican rhetoric of virtue arising from Rousseau's "The Social Contract," in which he postulates that a citizen is at the same time a subject-at the moment of submission and at the moment of action.

It is clear, however, that there are no ideal citizens in actuality. Moreover, having said that the people are citizens in the political sense, we must immediately, automatically conclude that they are obviously not citizens in the sense of such action, in the sense of involvement.

As we consider the logic of the nation and citizens, on the one hand, we get back, via Rousseau, to the roots of the republican tradition. On the other hand, we simultaneously identify the reality that we can describe in Weber's language, for instance, when talking about bureaucracy and about building the "iron cage."

\section{- In other words, a republic today cannot be a nation-state?}

- The demand not only for a state but for a state that is an effective civil entity is real. But these days even the ideal models of the nation-state which existed in some or another way in the first half of the 20th century and, partly, in its second half are falling apart and fading away even in the eyes of the proponents of such views. Even they come to understand that in the modern realities any nation in this republican sense is out of the question (see, for example, Bauman, 2004; Mair, 2013). Once again, we are faced with a dual problem - how to describe the existing reality and what to do with it.

Within the framework of this dichotomy, we think either according to the classical pattern, which basically refers to Central and Eastern Europe, about how the state emerges from the national community and when eventually the state begins to act as an agent of the national community. Or, on the contrary, we accept the fact that the state creates this community using its citizens, and this community is tied with this political regime. 
Naturally, this is an extremely abstract pattern. But the tricky thing is that however abstract, this pattern embraces for us at least some of the elements of the reality that we deal with. And this problem is described in the language of the national. The national is one of the key elements of this system. The national implies that the partakers of this joint action are expected to experience some feeling of affection towards their community. Consequently, they are expected to demonstrate something else apart from loyalty.

\section{NATIONAL FOREIGN POLICY}

- Is there such a thing as national foreign policy? And if there is, what is it?

- Yes, there is, of course. At least as a term, once we are talking about it. We use this term, and we fill it with some meanings. Of course, just as all basic political terms, such as 'politics,' 'nation,' or 'state,' it not so much describes and analyzes something as creates it; it is a performative, acting agent.

Whenever there emerges some group that positions itself as proxy empowered to act on behalf of the nation, it always proclaims that, on the one hand, it is building a nation, and on the other hand, that the nation is in a semifinished condition. This justifies the group's existence, its position and intention to perform some action.

This paradox has been described many times: in discussing a national policy we attribute this policy to some political community that we define as a "nation." At the same time, a number of actions and models of behavior that in one way or another are associated with the foreign policy of this political community are qualified as non- or anti-national actions and models (Brubaker, 2004, Ch. I).

Then we may either try to reformulate and reformat, for example, the notion 'national policy' as an analytical one. Or we may try to create our own neutral language for describing this phenomenon. The tricky thing is that the very saying of something in this context, the message expected to be heard is a variant of political action itself (Austin, 1962; Habermas, 1984, 1987).

\section{- What is the target audience of this message?}

- Target audiences vary. If we take, for example, the topic of the Russian Empire of the second half of the 19th century, which I mostly deal with, we 
will see that the audience changes depending on the context. It may be "society" in the good old sense of the word, or it may be a very narrow group of select few who make key decisions (or who are considered as such). The most important thing is to ensure that the texts appear on the table in front of them and the voiced message produces an effect on them.

In the case of a mass movement, the audience of the message may be very broad. Remarkably, the very same persons and the very same groups in different situations may work differently and refocus their attention. Moreover, for the participants in these movements the national discourse very often becomes a language of reflection, a means of self-analysis.

But in each case the main addressee of the message is its sender. He does not persuade some other, external listener that his ideas are right. The author narrates the message to himself, formulates the national and state interest for himself, and describes his own actions.

Take, for instance, the Slavophiles of the 1980s, who first held a discussion between themselves (being people of different generations: Khomyakov and Kireyevsky, on the one hand, and Samarin and Aksakov, on the other), built a common language and common vision of how they should understand national wellbeing, the goals and tasks for Russia, and so on. Naturally, they simultaneously debated with the Westernizers, but these arguments brought about a rapprochement. Khomyakov, Kireyevsky, Samarin, and Aksakov achieved agreement between themselves and similarity of certain views and reactions. Then there followed the most intense period of internal discussions, arguments and exchanges of letters that eased the debate on general issues and eventually produced some sort of "common understanding." Then that common vision began to be projected externally.

- But we are still unable to define the Russian, either in academic or normative terms. We have a very vague, elusive Russian. We have an empire with a status of post-empire and in a state of retreat or in an attempt to retain its positions and forced to claim a restored status without which it does not see its future. We have a multi-ethnic state whose parts are linked with each other, weakly or strongly. A logical question arises: Is a national policy, let alone a national foreign policy 
that is a derivative of a national domestic policy, possible in a situation like this?

- Yes, I think it is possible. It is a different matter, though, that a national foreign policy will eventually result in radical reformatting of the country itself. Suffice it to recall the events of the "Russian Spring," other possible developments and related questions that have been discussed in this connection, at the level of constructs as such. First of all, in what conditions Russia will be modified and what will be happening to it (Kildyushov, 2015; Krylov et al., 2016).

One of the hopes of Russian nationalists in the 2000s and the first half of the 2010s was that a proper national foreign policy would result in a national domestic policy, and a national policy would create a national community.

The capabilities and manifestations of a certain national policy, in turn, set in motion or trigger other development scenarios for the civil community. A classic example is Piedmont's ambition (and capability) to become the unifier of Italy, which largely transformed the kingdom's policy for a period of fifty years in the 19th century.

Another, no less illustrative example was the possibility for Prussia to act as the unifier of Germany-greater or smaller. As we now know, the unification of smaller Germany materialized. It is a history of many hesitations and a history of making choices...

- What should we postulate then-our readiness to act on behalf of Russianness, or on behalf of the Russian post-modern empire?

- As you have said yourself, anything goes. The question is what our goals are, what we seek, and to what extent we are ready, at least at the level of risks.

- Can we define this somehow? Are there any ideas as to what we seek and strive for?

- The way I see it, the costs of acting on behalf of the very same Russianness, the very same community after a series of hesitations are estimated to be far greater than likely gains. Accordingly, this policy seems to have been dropped. I believe that currently the stake is largely on post-imperialism, on acting in the capacity of the main inheritor of the 
imperial space, and not so much on playing a game of revanche-although on revanche, too, in a sense-as on playing in a greater part of the former imperial space and regarding it as our own sphere of influence/expansion.

\section{- Will then the internal post-imperial policy spread to this "own sphere"?}

- This is inevitable. There is no way of building a barrier between foreign and home policies. Moreover, expansion will be impossible without internal reconfiguration, without changing Russia itself. The history of Russia's internal re-assembly - which is well seen today -is largely a history of its foreign policy.

Russian historians Vasily Klyuchevsky and Pavel Milyukov explained Peter the Great's reforms through the Northern War, which brought the Russian Empire into being. The tax reform, industrial policies (with certain allowances), and Russia's division into gubernias at the beginning of the 18th century were immediate results of the military challenges.

And the other way round, new opportunities for foreign policies are opened up as a result of internal transformations.

\section{References}

Austin, J.L., 1962. How to Do Things with Words. Oxford University Press.

Bauman, Z., 2004. Identity: Conversations with Benedetto Vecchi. Cambridge: Polity.

Berger, S. and Miller, A. (eds.), 2015. Nationalizing Empires. Budapest: CEU.

Boltanski, L., 2012. Énigmes et complots. Une enquête à propos d'enquêtes. Paris: Gallimard.

Brubaker, R., 2004. Ethnicity Without Groups. Harvard University Press.

Drahomanov, M., 1915 (1893-1894). Lysty na Naddniprjans'ku Ukraïnu [Letters to the Middle-Dnieper Ukraine]. Kolomyja: Drukarnja M. Bilousa

Habermas, J., 1984 (1981). Theory of Communicative Action. Vol. 1: Reason and the Rationalization of Society. Transl. by Thomas A. McCarthy. Boston, Mass.: Beacon Press.

Habermas, J., 1987 (1981). Theory of Communicative Action. Vol. 2: Lifeworld and System: A Critique of Functionalist Reason. Transl. by Thomas A. McCarthy. Boston, Mass.: Beacon Press. 
Kildyushov, 0., 2015. Reshatsa li rossiyskiye "elity" na realny razryv s Zapadom [Will the Russian "Elites" Dare Break Up with the West?]. RusNext.ru, 20 September [online]. Available at: <rusnext.ru/news/1442744740> [Accessed 15 January 2021].

Krylov, K.A. et al., 2016. Yest' li budustcheye u russkogo natsionalizma? Ekspertny opros. [Does Russian Nationalism Have a Future? Experts' Inquiry] Voprosy natsionalizma, 27(3), pp. 3-18.

Krylov, K.A., 2010. Prognat' chertei [To Banish Demons]. Moscow: Skimen.

Lyotard, J. F., 1984 (1979). The Postmodern Condition: A Report on Knowledge. Transl. by Geoffrey Bennington and Brian Massumi. Minneapolis: University of Minnesota Press.

Mair, P., 2013. Ruling the Void: The Hollowing of Western Democracy. L.: Verso.

Meinecke, F., 1924. Die Idee Der Staatsräson In Der Neueren Geschichte. München: R. Oldenbourg.

Osterhammel, J., 2014. The Transformation of the World: A Global History of the Nineteenth Century. Princeton University Press.

Reizov, B., 1958. Frantsuzsky istorichesky roman $v$ epohu romantizma [French Romantic Historical Novel]. Leningrad: Gosudarstvennoe izdatel'stvo hudozhestvennoi literatury.

Sergeev, S., 2010. Prishestvie natsii? Kniga statei [The Advent of the Nation? A Collection of Articles]. Moscow: Skimen.

Sergeev, S., 2017. Russkaya natsiya ili Rasskaz ob istorii eyo otsutstviya [Russian Nation or The Narrative of the History of Its Absence]. Moscow: Centrpoligraf. Stalin, J., 1913. Natsionalny vopros i sotsial-demokratiya [Ethnic Issues and the Social-Democratic Movement]. Prosveshchenie, Vol. 3, 4, 5.

Teslya, A., 2014. Sozdavaya politicheskuyu natsiyu: Vyacheslav Lipinsky i yego konservativnaya teoriya 1920-h godov [Creating Political Nation: Vyacheslav Lypynsky and His Conservative Theory of the 1920s]. Sotsiologicheskoye obozrenie, 13(3), pp. 33-63.

Teslya, A., 2016. Natsionalno-politicheskie vzglyady M.P. Drahomanova 1888$1895 \mathrm{gg}$. [The National-Political Views of M. P. Drahomanov in 1888-1895]. Sotsiologicheskoye obozrenie, 15(1), pp. 94-111. D0I: 10.17323/1728-192X2016-1-94-111

Vishlenkova, E., 2011. Vizualnoe narodovedenie imperii, ili "Uvidet' russkogo dano ne kazhdomu" [Visual Ethnology of the Empire, or "Not Everyone Can See the Russian"]. Moscow: Novoye Literaturnoye Obozrenie. 